\title{
Multiple Decision Making Criteria in the Implementation of Renewable Energy Sources
}

\author{
Dejan JOVANOVIĆ, Dragan CVETKOVIĆ
}

\begin{abstract}
Production of electricity from renewable energy sources is a challenge of power sector. The final decision in choosing renewable energy source must be made in accordance with stakeholder value. PROMETHEE method as tool for stakeholder value was used in this paper to do ranking of renewable energy sources. Stakeholder value sets criteria, with different weight depending on the stakeholder, to which the method can be applied. Defined criteria could be used as standards (Renewable Portfolio Standards) in the application of renewable energy sources. The expected result is the answer to the question whether the state and investors can intersect on the same renewable energy source from which both stakeholders expect the biggest interest. According to the applied methodology, number of stakeholders and criteria is endless.
\end{abstract}

Keywords: biomass; cogeneration (CHP); geothermal energy; mini hydro; National Renewable Energy Action Plan (NAPOIE); production of electricity; PROMETHEE method; Renewable Energy Sources (RES); Renewable Portfolio Standards (RPS); solar; stakeholder value; wind

\section{INTRODUCTION}

Renewable Portfolio Standards (RPS) define the methodology and criteria according to which a minimal percentage is established for the electricity that has to be provided from renewable energy sources.

On its own, it presents a considerable challenge for a successful implementation. The basic idea is to show a mathematical model which can be used in the application of RPS standards, as well as to give a proposition of standards (criteria) which can be used for future analyses.

Key elements that are taken into account are available sources, socio-economic and technical characteristics, political and business interests.

A successful RPS policy must balance the goals of the State regarding diversity of fuels, economic development, price effects and environmental protection. (Cori and Svezei, 2007) [2].

Some authors point out that it is exactly those political and economic factors which can influence a state's decision to conduct RPS (Fovler and Brin, 2013 [5]; Chandler, 2009 [6]; Huang et al., 2007 [7]; Lion and Iin, 2010 [8]).

The state, as a stakeholder, may opt for the application of RPS standards for several reasons: to diversify sources for the production of electricity, to encourage and instigate investments in the renewable sources sector. (Lyon and Yin, 2010).

Investors, as bearers of progress and instigators of economic activity, scrutinize the area in which they would invest their money.

The relation between the State and the Investors should absolutely be founded on their mutual interests with clear priorities and a methodology upon which those interests should be based.

The PROMETHEE method enables us to make connection between seemingly unlikable parameters and is therefore an ideal tool for RPS analyses.

Official data were used as information source, and they are also the goals for the application and usage of renewable energy sources published in the National Renewable Energy Action Plan of the Republic of Serbia (NAPOIE). According to the NAPOIE total of $2252 \mathrm{GW} \cdot \mathrm{h}$ should be obtained from mini hidros, biomass, solar, wind and geothermal sources.
The goal of this paper is to rank renewable energy sources according to hypothetical scenarios. Different scenarios are defined in such a manner that every renewable energy source taken into account delivers the total of the expected amount of $\mathrm{GW} \cdot \mathrm{h}$ to the electric energy system, according to stakeholders. In addition to establishing priorities between different RES for each of the stakeholders, which is the main idea of this paper, and finding whether this sequence is equal to the one set by NAPOIE as target value for the participation of every type of renewable energy sources, we also aim to answer the question which type of renewable energy sources is the best for use. Every renewable energy source taken into account can independently produce the amount of electricity that the plan intends for all analysed renewable energy sources to deliver together.

Expected results: Which RES is the best for usage between analysed types, for both the State and the investors, and in which way every given standard (criterion) influences the final result.

Explanation of results: RES ranking is important for establishing of priorities of both the state and the investors. We also want to establish whether the priorities of the stakeholders are identical.

\subsection{Research Methodology}

Jan Pierre developed methodology used in this paper. The PROMETHEE method (Preference Ranking Organization Method for Enrichment Evaluations) belongs to the multi-criteria decision making model. It is very useful in cases where a decision maker has to make choices from several alternatives and criteria that are conflicting between each other. A large number of different criteria provides a comprehensive insight in accordance with the requirements or conditions set by the decision maker. Criteria can be presented to different units, often of varying relative importance, and for different requirements for maximizing and minimizing.

Usage of this method is possible within the defining basic parameters so the model could be applied. In this paper, the following input data (parameters) were chosen:

- stakeholders

- criteria

- importance weight coefficients 
- $\quad$ preference functions (for every criterion)

- proposed scenarios.

Stakeholders considered in ranking:

- $\quad$ state (DR),

- $\quad$ potential investors $(\mathrm{PI})$.

Criteria (Standards) on the basis of which the research was performed were defined by the authors (Tab. 1)

These 10 criteria can be divided into two categories:

1) Quantitative criteria, (C1, C2, C3, C5, C9, C10) [5]

2) Ranking criteria $(\mathrm{C} 4, \mathrm{C} 6, \mathrm{C} 7, \mathrm{C} 8)$.

Table 1 Criteria for ranking scenarios [11]

\begin{tabular}{|l|l|}
\hline C1 & Utilization of available resources (Maximum) \\
\hline C2 & The price of the installed capacity ( planed) \\
\hline C3 & The incentive buying price \\
\hline C4 & stage of development technology \\
\hline C5 & Planned work hours \\
\hline C6 & CHP sensitivity \\
\hline C7 & local business and welfare impact \\
\hline C8 & Social and environmental impact \\
\hline C9 & Pay back period \\
\hline C10 & Installed power \\
\hline
\end{tabular}

Importance of weight coefficients are given in Tab. 2 . Noted criteria treat stakeholders according to the three levels of importance:

- $\quad$ High level of importance (HLI)

- Normal level of importance (NLI)
- $\quad$ Low level of importance (LLI).

The calculation of Importance of weight coefficients was also made in the manner defined by the PROMETHEE methodology, and $\mathrm{C}$ values attributed on scale from 1-10, starting from the categorization of criteria.

It is interesting to point out the influence of criterion C6 - CHP sensitivity, which has the same 9,09\% influence weight on both stakeholders. We may, therefore, conclude that, aside from those criteria marked as very important for all sides, criterion $\mathrm{K} 6$ is the first one that needs to be agreed upon next, i.e. to make cogenerative systems (CHP)

Preference functions. A mathematical preference function is proposed for all criteria. In this research, the following allocations are proposed:

- Preference function 1. It is for criteria C6. It is a usual function, since CHP sensitivity is possible or not.

- Preference function 3. It is for criteria C2, C3, C5, $\mathrm{C} 9, \mathrm{C} 10$. It is a V shape type of function with decision lead by difference $m=d_{\max }$.

- Preference function 4. It is for criteria C1, C4, C7, C8. It is level type of function with difference values $0,1 / 2$, 1 ( $m$ and $n$ are decision-making limits). For $\mathrm{C} 1$, proposed decision-making limits are $m=10 \% d_{\max }$, and $n=30 \% d_{\max }$, and for C4, C7, C8 $m=1$ and $n=2$.

- N.B.: Mathematical functions were chosen according to the sequence described by the PROMETHEE method [2].

Table 2 Calculation of importance of weight coefficients [11]

\begin{tabular}{|c|c|c|c|}
\hline $\mathrm{DR}$ & Importance of weight coefficients $t_{i}$ & $\sum t_{i}$ & 0,1636 \\
\hline $\mathrm{k} 1 ; \mathrm{k} 5 ; \mathrm{k} 10$ & $(8+9+10) / 3=9$ & 0,0909 & HLI $16,36 \%$ \\
\hline $\mathrm{k} 2 ; \mathrm{k} 3 ; \mathrm{k} 6 ; \mathrm{k} 7 ; \mathrm{k} 8$ & $(3+4+5+6+7) / 5=5$ & 0,02727 & NLI $9,09 \%$ \\
\hline $\mathrm{k} 4 ; \mathrm{k} 9$ & $(1+2) / 2=1,5$ & & \\
\hline $\mathrm{PI}$ & & 0,154545 & \\
\hline $\mathrm{k} 2 ; \mathrm{k} 3 ; \mathrm{k} 4 ; \mathrm{k} 9$ & $(7+8+9+10) / 4=8,5$ & 0,0909 & HLI $15,45 \%$ \\
\hline $\mathrm{k} 5 ; \mathrm{k} 6 ; \mathrm{k} 10$ & $(4+5+6) / 3=5$ & 0,03636 & NLI $9,09 \%$ \\
\hline $\mathrm{k} 1 ; \mathrm{k} 7 ; \mathrm{k} 8$ & $(1+2+3) / 3=2$ & LLI 3,63\% \\
\hline
\end{tabular}

\subsection{Propopsed Scenarios}

The proposed scenarios are as follows:

- Proposed scenario (A1) - set according to the NAPOIE goals.

- Proposed scenario (A2) - is proposed within usage of mini hydros as main RES.

- Proposed scenario (A3) - is proposed with in usage of biomass as main RES.

- Proposed scenario (A4) - is proposed within usage of sun as main RES.
- $\quad$ Proposed scenario (A5) - is proposed with in usage of wind as main RES.

- Proposed scenario (A6) - is proposed within usage of geothermal as main RES.

- $\quad$ N.B.: Models are suggested by the authors of this paper.

\section{RESEARCH RESULTS}

The following tables contain the results of the research.

Table 3 Scenarios A1 to A6 [4]

\begin{tabular}{|c|c|c|c|c|c|c|c|}
\hline & & A1 & $\mathrm{A} 2$ & A3 & A4 & A5 & $\mathrm{A} 6$ \\
\hline & & $\mathrm{GW} \cdot \mathrm{h}$ & $\mathrm{GW} \cdot \mathrm{h}$ & $\mathrm{GW} \cdot \mathrm{h}$ & $\mathrm{GW} \cdot \mathrm{h}$ & $\mathrm{GW} \cdot \mathrm{h}$ & $\mathrm{GW} \cdot \mathrm{h}$ \\
\hline \multirow{2}{*}{ Hydro potential } & $>10 \mathrm{MW}$ & 1108 & 1108 & 1108 & 1108 & 1108 & 1108 \\
\hline & $<10 \mathrm{MW}$ & 592 & 2252 & 0 & 0 & 0 & 0 \\
\hline Biomass & & 640 & 0 & 2252 & 0 & 0 & 0 \\
\hline Solar & & 13 & 0 & 0 & 2252 & 0 & 0 \\
\hline Wind & & 1000 & 0 & 0 & 0 & 2252 & 0 \\
\hline Geothermal energy & & 7 & 0 & 0 & 0 & 0 & 2252 \\
\hline TOTAL & & 3360 & & & & & \\
\hline
\end{tabular}


Table 4 Available potentials of renewable energy sources [9]

\begin{tabular}{|l|c|c|}
\hline Renewable energy source type & Mtoe & GW·h \\
\hline Hydro & 0,8 & 9304 \\
\hline Biomass & 2,25 & 26167 \\
\hline Solar & 0,6 & 6978 \\
\hline Wind & 0,2 & 2326 \\
\hline Geothermal & 0,2 & \\
\hline
\end{tabular}

Table 5 Scenarios according to $K$ criteria values [11]

\begin{tabular}{|c|c|c|c|c|c|c|c|c|c|c|c|}
\hline & & $\mathrm{C} 1$ & $\mathrm{C} 2$ & $\mathrm{C} 3$ & $\mathrm{C} 4$ & $\mathrm{C} 5$ & C6 & $\mathrm{C} 7$ & $\mathrm{C} 8$ & C9 & $\mathrm{C} 10$ \\
\hline $\mathrm{A} 1$ & PLAN & $43,00 \%$ & $1.356 .627 .968 €$ & 9,87 & 4 & 3564 & 1 & 3 & 4 & 6,1 & 799 \\
\hline A2 & Hydro potential $<10 \mathrm{MW}$ & $24,20 \%$ & $1.998 .203 .175 €$ & 9,89 & 5 & 3150 & 0 & 2 & 4 & 9,0 & 715 \\
\hline A3 & Biomass & $8,61 \%$ & $1.591 .178 .750 €$ & 10,74 & 4 & 6400 & 1 & 4 & 4 & 6,6 & 352 \\
\hline A4 & Solar & $32,27 \%$ & $4.330 .769 .231 €$ & 18,45 & 3 & 1300 & 0 & 1 & 3 & 10,4 & 1732 \\
\hline A5 & Wind & $96,82 \%$ & $1.595 .542 .000 €$ & 9,20 & 4 & 2000 & 0 & 1 & 3 & 7,7 & 1126 \\
\hline A6 & Geothermal energy & $96,82 \%$ & $1.323 .854 .286 €$ & 8,30 & 4 & 7000 & 1 & 2 & 5 & 7,1 & 322 \\
\hline
\end{tabular}

\begin{tabular}{|l|c|}
\hline CRITERION C4 - STAGE OF DEVELOPMENT TECHNOLOGY \\
\hline laboratory phase & 1 \\
\hline Pilot phase & 2 \\
\hline Further improvement phase & 3 \\
\hline Commercial phase for local market & 4 \\
\hline Commercial phase worldwide & 5 \\
\hline
\end{tabular}

CRITERION C7 - LOCAL BUSINESS AND WELFARE IMPACT

\begin{tabular}{|l|l|}
\hline No impact & 1 \\
\hline Low impact & 2 \\
\hline Small impact & 3 \\
\hline Large impact & 4 \\
\hline Very large impact. & 5 \\
\hline
\end{tabular}

\begin{tabular}{|l|c|}
\hline CRITERION C8 - SOCIAL AND ENVIRONMENT IMPACT \\
\hline Against technology & 1 \\
\hline Split opinion & 2 \\
\hline Accepted technology (vis-res) & 3 \\
\hline Accepted technology (res) & 4 \\
\hline Majority are pro installations & 5 \\
\hline
\end{tabular}

\subsection{Mathematical Model Representation for the State as a Stakeholder [11]}

\begin{tabular}{|c|c|c|c|c|c|c|c|c|c|c|c|}
\hline & \multirow{2}{*}{ State } & $\min$ & $\min$ & $\min$ & $\max$ & $\max$ & $\max$ & $\max$ & $\max$ & $\min$ & $\max$ \\
\hline & & C1\% & $\mathrm{C} 2 €$ & $\mathrm{C} 3$ & $\mathrm{C} 4$ & $\mathrm{C} 5$ & C6 & $\mathrm{C} 7$ & $\mathrm{C} 8$ & $\mathrm{C} 9$ & $\mathrm{C} 10$ \\
\hline $\mathrm{A} 2$ & Hydro potential $<10 \mathrm{MW}$ & 0,2420 & $1.998 .203 .175 €$ & 9,89 & 5 & 3150 & 0 & 2 & 4 & 9,0 & 715 \\
\hline A3 & Biomass & 0,0861 & $1.591 .178 .750 €$ & 10,74 & 4 & 6400 & 1 & 4 & 4 & 6,6 & 352 \\
\hline A4 & Solar & 0,3227 & $4.330 .769 .231 €$ & 18,45 & 3 & 1300 & 0 & 1 & 3 & 10,4 & 1732 \\
\hline A5 & Wind & 0,9682 & $1.595 .542 .000 €$ & 9,20 & 4 & 2000 & 0 & 1 & 3 & 7,7 & 1126 \\
\hline A6 & Geothermal energy & 0,9682 & $1.323 .854 .286 €$ & 8,30 & 4 & 7000 & 1 & 2 & 5 & 7,1 & 322 \\
\hline
\end{tabular}

\begin{tabular}{|c|c|c|c|c|}
\hline \multicolumn{5}{|c|}{ Determination of preference index } \\
\hline $\mathrm{IP}(\mathrm{a} 2, \mathrm{a} 3)$ & $\mathrm{IP}(\mathrm{a} 2, \mathrm{a} 4)$ & IP(a2.a5) & IP(a2,a6) & \multirow{10}{*}{$\begin{array}{c}\text { N.B.: } \\
\mathrm{IP}=\left(a_{i}, a_{s}\right), \\
i, s=2,3,4,5,6 \\
\mathrm{IP}=\sum t_{j} P_{j}\left(a_{i}, a_{s}\right)\end{array}$} \\
\hline 0,1736 & 0,49084 & 0,369567 & 0,340835 & \\
\hline $\mathrm{IP}(\mathrm{a} 3, \mathrm{a} 2)$ & $\mathrm{IP}(\mathrm{a} 3, \mathrm{a} 4)$ & $\mathrm{IP}(\mathrm{a} 3, \mathrm{a} 5)$ & $\mathrm{IP}(\mathrm{a} 3, \mathrm{a} 6)$ & \\
\hline 0,398447 & 0,695355 & 0,5399 & 0,421672 & \\
\hline $\mathrm{IP}(\mathrm{a} 4, \mathrm{a} 2)$ & $\mathrm{IP}(\mathrm{a} 4, \mathrm{a} 3)$ & $\mathrm{IP}(\mathrm{a} 4, \mathrm{a} 5)$ & $\mathrm{IP}(\mathrm{a} 4, \mathrm{a} 6)$ & \\
\hline 0,117956 & 0,160001 & 0,233948 & 0,3272 & \\
\hline $\mathrm{IP}(\mathrm{a} 5, \mathrm{a} 2)$ & $\mathrm{IP}(\mathrm{a} 5, \mathrm{a} 3)$ & $\mathrm{IP}(\mathrm{a} 5, \mathrm{a} 4)$ & $\mathrm{IP}(\mathrm{a} 5, \mathrm{a} 6)$ & \\
\hline 0,116733 & 0,172473 & 0,386305 & 0,1636 & \\
\hline $\mathrm{IP}(\mathrm{a} 6, \mathrm{a} 2)$ & $\mathrm{IP}(\mathrm{a} 6, \mathrm{a} 3)$ & $\mathrm{IP}(\mathrm{a} 6, \mathrm{a} 4)$ & $\mathrm{IP}(\mathrm{a} 6, \mathrm{a} 5)$ & \\
\hline 0,29712 & 0,92625 & 0,613555 & 0,391871 & \\
\hline
\end{tabular}

\begin{tabular}{|c|c|c|c|c|c|c|c|}
\hline & $\mathrm{a} 2$ & $\mathrm{a} 3$ & $\mathrm{a} 4$ & $\mathrm{a} 5$ & $\mathrm{~T} 6$ & $\mathrm{~T}+$ \\
\hline $\mathrm{a} 2$ & 0 & 0,1736 & 0,49084 & 0,369567 & 0,340835 & 0,343711 & 0,111147 \\
\hline $\mathrm{a} 3$ & 0,398447 & 0 & 0,695355 & 0,5399 & 0,421672 & 0,513844 \\
\hline $\mathrm{a} 4$ & 0,117956 & 0,160001 & 0 & 0,233948 & 0,3272 & 0,364169 \\
\hline $\mathrm{a} 5$ & 0,116733 & 0,172473 & 0,386305 & 0 & 0,1636 & 0,209776 \\
\hline $\mathrm{a} 6$ & 0,29712 & 0,092625 & 0,613555 & 0,391871 & 0 & 0,33674 \\
\hline T- & 0,232564 & 0,149675 & 0,546514 & 0,383822 & 0,313327 & 0,17404 \\
\hline
\end{tabular}




\subsection{Mathematical Model Representation for the Investors as Stakeholders [11]}

\begin{tabular}{|c|c|c|c|c|c|c|c|c|c|c|c|}
\hline & \multirow{2}{*}{ Investors } & $\min$ & $\min$ & $\max$ & $\max$ & $\max$ & $\max$ & $\max$ & $\max$ & $\min$ & $\max$ \\
\hline & & $\mathrm{C} 1 \%$ & $\mathrm{C} 2 €$ & $\mathrm{C} 3$ & $\mathrm{C} 4$ & $\mathrm{C} 5$ & C6 & $\mathrm{C} 7$ & $\mathrm{C} 8$ & C9 & $\mathrm{C} 10$ \\
\hline $\mathrm{A} 2$ & Hydro potential $<10 \mathrm{MW}$ & 0,2420 & $1.998 .203 .175 €$ & 9,89 & 5 & 3150 & 0 & 2 & 4 & 9,0 & 715 \\
\hline A3 & Biomass & 0,0861 & $1.591 .178 .750 €$ & 10,74 & 4 & 6400 & 1 & 4 & 4 & 6,6 & 352 \\
\hline A4 & Solar & 0,3227 & $4.330 .769 .231 €$ & 18,45 & 3 & 1300 & 0 & 1 & 3 & 10,4 & 1732 \\
\hline A5 & Wind & 0,9682 & $1.595 .542 .000 €$ & 9,20 & 4 & 2000 & 0 & 1 & 3 & 7,7 & 1126 \\
\hline A6 & Geothermal energy & 0,9682 & $1.323 .854 .286 €$ & 8,30 & 4 & 7000 & 1 & 2 & 5 & 7,1 & 322 \\
\hline
\end{tabular}

\begin{tabular}{|c|c|c|c|c|}
\hline \multicolumn{5}{|c|}{ Determination of preference index } \\
\hline $\mathrm{IP}(\mathrm{a} 2, \mathrm{a} 3)$ & $\mathrm{IP}(\mathrm{a} 2, \mathrm{a} 4)$ & $\mathrm{IP}(\mathrm{a} 2, \mathrm{a} 5)$ & $\mathrm{IP}(\mathrm{a} 2, \mathrm{a} 6)$ & \multirow{10}{*}{$\begin{array}{c}\text { N.B.: } \\
\mathrm{IP}=\left(a_{i}, a_{s}\right), \\
i, s=2,3,4,5,6 \\
\mathrm{IP}=\sum t_{j} P_{j}\left(a_{i}, a_{s}\right)\end{array}$} \\
\hline 0,1611 & 0,590895 & 0,272998 & 0,359078 & \\
\hline $\mathrm{IP}(\mathrm{a} 3, \mathrm{a} 2)$ & $\mathrm{IP}(\mathrm{a} 3, \mathrm{a} 4)$ & $\mathrm{IP}(\mathrm{a} 3, \mathrm{a} 5)$ & $\mathrm{IP}(\mathrm{a} 3, \mathrm{a} 6)$ & \\
\hline 0,377197 & 0,640883 & 0,402209 & 0,33841 & \\
\hline $\mathrm{IP}(\mathrm{a} 4, \mathrm{a} 2)$ & $\mathrm{IP}(\mathrm{a} 4, \mathrm{a} 3)$ & $\mathrm{IP}(\mathrm{a} 4, \mathrm{a} 5)$ & $\mathrm{IP}(\mathrm{a} 4, \mathrm{a} 6)$ & \\
\hline 0,195746 & 0,206178 & 0,21615 & 0,281805 & \\
\hline $\mathrm{IP}(\mathrm{a} 5, \mathrm{a} 2)$ & $\mathrm{IP}(\mathrm{a} 5, \mathrm{a} 3)$ & $\mathrm{IP}(\mathrm{a} 5, \mathrm{a} 4)$ & $\mathrm{IP}(\mathrm{a} 5, \mathrm{a} 6)$ & \\
\hline 0,143413 & 0,087446 & 0,477263 & 0,245445 & \\
\hline $\mathrm{IP}(\mathrm{a} 6, \mathrm{a} 2)$ & $\mathrm{IP}(\mathrm{a} 6, \mathrm{a} 3)$ & $\mathrm{IP}(\mathrm{a} 6, \mathrm{a} 4)$ & $\mathrm{IP}(\mathrm{a} 6, \mathrm{a} 5)$ & \\
\hline 0,294074 & 0,041479 & 0,622703 & 0,267196 & \\
\hline
\end{tabular}

\begin{tabular}{|c|c|c|c|c|c|c|c|}
\hline & $\mathrm{a} 2$ & a3 & $\mathrm{a} 4$ & a5 & a6 & $\mathrm{T}+$ & $\mathrm{T}$ \\
\hline $\mathrm{a} 2$ & 0 & 0,1611 & 0,590895 & 0,272998 & 0,359078 & 0,346018 & 0,09341 \\
\hline a3 & 0,377197 & 0 & 0,640883 & 0,402209 & 0,33841 & 0,439675 & 0,315624 \\
\hline $\mathrm{a} 4$ & 0,195746 & 0,206178 & 0 & 0,21615 & 0,281805 & 0,22497 & $-0,35797$ \\
\hline a5 & 0,143413 & 0,087446 & 0,477263 & 0 & 0,245445 & 0,238392 & $-0,05125$ \\
\hline a6 & 0,294074 & 0,041479 & 0,622703 & 0,267196 & 0 & 0,306363 & 0,000179 \\
\hline $\mathrm{T}-$ & 0,2526075 & 0,124051 & 0,582936 & 0,289638 & 0,306185 & & \\
\hline
\end{tabular}

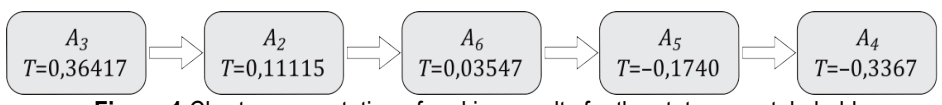

Figure 1 Chart representation of ranking results for the state as a stakeholder

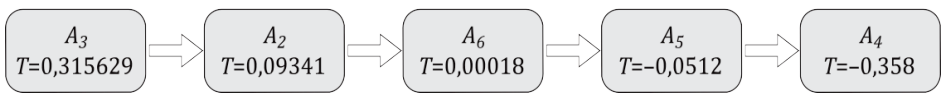

Figure 2 Chart representation of ranking results for the investors as stakeholders

\section{CHART REPRESENTATION OF RESULTS}

Figs. 1 and 2 give chart representations of results for the state, investors and local community as stakeholders.

\section{CONCLUSION}

PROMETHEE methodology proved to be an excellent tool for stakeholder value and for analysing criteria, which were used for setting RES. Conclusion will be approached from two points. One is a) to analyse criteria seated up and weights toward stakeholders, and b) second will be to give a comment regarding the goals seated up by NAPOIE in way of RES priority for electricity production.

a) Final result / achieved ranking / could lead to conclusion in two possible ways. 1) First would be if ranking was different for analysed stakeholders. In that case, the goal would be to find which criteria affect difference the most and mark it as the most important one (this is not a case in this paper) and 2) the second one, which is the case in this paper, is when achieved ranking is the same for both stakeholders. In that case, conclusion could be made that assuming weights of criteria were set up correctly toward stakeholders, since none of them had strong impact on the result.

Although three criteria, C1 - Utilization of available resources (Maximum), C4 - stage of development technology, and C9 - Pay back period, had completely opposite weights (for State $\mathrm{C} 1=16,36 \%$, and $\mathrm{C} 4 / \mathrm{C} 9=2,72 \%$, and for investors $\mathrm{C} 1=3,63 \%$, and $\mathrm{C} 4 / \mathrm{C} 9=15,45 \%$ ), for analysed stakeholders final ranking was the same which indicates accuracy of the obtained results.

Analysing criteria C2, C3, C5, it is clear that the State sees the priority supply safeness and working hours relative to price according to planned installed capacity and Incentive purchase price. The investors have a completely opposite approach, which is expected.

Criteria C6 - CHP sensitivity had the same weight for both stakeholders (important level) and did not affect final result anyhow. Taking this into consideration a conclusion could be made that this criterion brings up benefit to the usage of RES and should be a part of all analyses and standards.

Contribution to local development and welfare $\mathrm{C} 7$, and Social acceptability and sustainability of other influences on the environment $\mathrm{C} 9$, are with little importance for investors and with important weigh for the state. It would be interesting for some future research to check impact on the RES ranking if these two criteria were with the very important weight.

b) Official ranking RES, according to the NAPOIE, is as follows:

1) Wind energy

2) Biomass

3) Mini hydrous

4) Solar energy 
5) Geothermal energy.

From the point, amount of $\mathrm{GW} \cdot \mathrm{h}$ delivered in to the power system.

Results obtained by applied methodology ranked RES as follows:

1) Biomass

2) Mini hydrous

3) Geothermal energy

4) Wind energy

5) Solar energy.

Besides the difference on the first ranked RES the biggest difference is on Wind energy which lost first position and get on the $4^{\text {th }}$ place.

Importance of this result is because it changes state priorities regarding the followed activities for creating business, political and regulatory issues for promoting certain RES.

This result opens new research options in direction to do optimization of archived results on the way to assume new percentage of RES for production the same amount of electricity, and that new distribution to be compared with NAPOIE one on the same way, and see which result is better.

\section{REFERENCES}

[1] Jensen, M. C. (2000). Value Maximization and Stakeholder Theory. Working knowledge.

[2] http://hbswk.hbs.edu/item/value-maximization-andstakeholder-theory

[3] Cory, K. S. \& Swezey, B. G. (2007). Renewable Portfolio Standards in the States: Balancing goals and implementation. Technical report NREL/TP-670-41409. National Renewable Energy Laboratory.

[4] Čupić, M. \& Suknović, M. (2010). Odlučivanje, Fakultet organizacionih nauka, Beograd.

[5] Nacionalni Akcioni Plan za Obnovljive izvore Energije, Ministarstvo energetike, razvoja i zaštite životne sredine, Beograd 2013.

Fowler, L. \& Breen, J. (2013). The impact of political factors on states' adoption of renewable portfolio standards. Electr. J. 26(2), 79-94. https://doi.org/10.1016/j.tej.2013.01.007

Chandler, J. (2009). Trendy solutions: Why do states adopt Sustainable Energy Portfolio Standards? Energy Policy, 37, 3274-3281. https://doi.org/10.1016/j.enpol.2009.04.032

[6] Huang, M.-Y., Alavalapati, J. R., Carter, D. R., \& Langholtz, M. H. (2007). Is the choice of renewable portfolio standards random? Energy Policy, 35, 5571-5575. https://doi.org/10.1016/j.enpol.2007.06.010

[7] Lyon, T. P. \& Yin, H. (2010). Why do states adopt renewable portfolio standards?: An empirical investigation. Energy $J$. 31(3), 133-157. https://doi.org/10.5547/ISSN0195-6574-EJ-Vol31-No3-7

[8] Politika Republike Srbije u oblasti obnovljivih izvora energije, Ministarstvo energetike, razvoja i zaštite životne sredine, Privredna Komora Srbije, Beograd 10. decembar 2012.

[9] Jovanovic, D. \& Pribicevic, I. (2017). Multi-Criteria Decision-Making in the Implementation of Renewable Energy Sources, Computer Simulation Dragan Cvetkovic, IntechOpen, Available from: https://www.intechopen.com/ books/computer-simulation/multi-criteria-decision-makingin-the-implementation-of-renewable-energy-sources https://doi.org/10.5772/67734

\section{Contact information:}

\section{Dejan JOVANOVIC}

JP Zavod za udzbenike

Oblicev venac br. 511000 Beograd, R. Srbija

Tel.: +381648021002, +381637701846

deki.jovanovic@gmail.com

\section{Dragan CVETKOVIC}

Univerzitet Singidunum

Danijelova 32, 11000 Beograd, R. Srbija

Tel.: +381653093322

dcvetkovic@singidunum.ac.rs 